\title{
Caracterização de um Isolado do Bean rugose mosaic virus (BRMV) de Minas Gerais e Estimativa de Perdas em Feijoeiro em Infecção Simples ou em Conjunto com o BCMV
}

\author{
Gloria P. Castillo-Urquiza ${ }^{1}$, Felipe G.M. Maia ${ }^{1}$, Murilo G. Carvalho ${ }^{1}$, \\ Cleide M.F. Pinto ${ }^{2}$ \& F. Murilo Zerbini ${ }^{1}$ \\ 'Departamento de Fitopatologia, BIOAGRO, Universidade Federal de Viçosa, e-mail: zerbini@ufv.br; \\ ${ }^{2}$ Centro Tecnológico da Zona da Mata, EPAMIG, Cx. Postal 216, CEP 36570-000, Viçosa, MG
}

(Aceito para publicação em 08/11/2006)

Autor para correspondência: F. Murilo Zerbini

CASTILlO-URQUiZA, G.P., MAIA, F.G.M., CARVAlHO, M.G., PINTO, C.M.F. \& ZERBINI, F.M. Caracterização de um isolado do Bean rugose mosaic virus (BRMV) de Minas Gerais e estimativa de perdas em feijoeiro em infecção simples ou em conjunto com o BCMV. Fitopatologia Brasileira 31:455-461. 2006.

\begin{abstract}
RESUMO
Plantas de feijão-vagem do cultivar Novirex apresentando mosaico e enrolamento de vagens, sem deformação foliar evidente, foram coletadas em 2002 em Cordisburgo, MG. Estudos preliminares identificaram o vírus como um isolado do Bean rugose mosaic virus (BRMV). Este trabalho relata a caracterização do isolado, por meio de produção e avaliação de anti-soro, determinação da gama de hospedeiros, estudo da transmissão do vírus por besouros crisomelídeos e estimativa de perdas em feijoeiro como resultado de infecção isolada ou em conjunto com o Bean common mosaic virus (BCMV). O roteiro adotado para purificação possibilitou a obtenção de vírus purificado em rendimento satisfatório para a produção de anti-soro. A titulação dos anti-soros foi realizada por ELISA indireto, obtendo-se reações positivas com a diluição máxima testada (1:70.000). Das 22 espécies vegetais utilizadas na gama de hospedeiros, foram infectadas plantas de Chenopodium quinoa e alguns cultivares de feijão e soja, conforme esperado para o BRMV. O isolado de BRMV foi transmitido pelo besouro crisomelídeo Cerotoma arcuata a uma taxa de 33,3\%. A infecção simples de feijão 'Ouro Negro' e de feijão-vagem 'Novirex' levou a uma redução do peso das vagens por planta de 3,4\% e 84,9\%, respectivamente. Infecção mista do BRMV com o BCMV levou a uma redução do peso de vagens por planta de até 70,1\% para 'Novirex' e de até 90,8\% para 'Ouro Negro'.
\end{abstract}

Palavras-chave adicionais: feijão, feijão-vagem, Bean rugose mosaic virus.

\begin{abstract}
Characterization of a Bean rugose mosaic virus (BRMV) isolate from Minas Gerais, and yield loss estimate in beans upon single infection and double infection with BCMV

Bean plants of the cultivar Novirex, showing an atypical pod curling symptom without mosaic or leaf distortion, were collected in 2002 at Cordisburgo, MG. Previous studies identified the virus as an isolate of Bean rugose mosaic virus (BRMV). This work reports on the characterization of the isolate, including its purification and production of a polyclonal antiserum, determination of a partial host range, vector transmission, and an estimate of yield losses due to single or mixed infection with Bean common mosaic virus (BCMV). The protocol adopted for virus purification led to purified preparations with high yield, and the antisera obtained reacted with the maximum dilution tested (1:70.000) in indirect ELISA. From the 22 plant species tested as hosts, Chenopodium quinoa reacted with chlorotic local lesions, which evolved to mosaic and leaf distortion in non-inoculated leaves. Bean and soybean cultivars reacted with mosaic and leaf distortion of varying intensity, as expected for BRMV. The isolate was transmitted by Cerotoma arcuata to $33.3 \%$ of the inoculated plants. Single infection of 'Ouro Negro' and 'Novirex' beans caused a reduction in the total weight of pods per plant of 3.4\% and $84.9 \%$, respectively. Mixed infection with BCMV caused a reduction of pod weight per plant of up to $70.1 \%$ in 'Novirex' and up to $90.8 \%$ in 'Ouro Negro'.
\end{abstract}

Additional keywords: common bean, Bean rugose mosaic virus.

\section{INTRODUÇÃO}

O mosaico rugoso do feijoeiro, causado pelo Bean rugose mosaic virus (BRMV; Comoviridae, Comovirus), foi

\footnotetext{
*Parte da Dissertação de Mestrado do primeiro autor. Universidade Federal de Viçosa. 2004.
}

relatado pela primeira vez na Costa Rica (Gamez, 1972). No Brasil, doença com sintomatologia similar foi denominada de mosaico-em-desenho e o seu agente de "vírus do mosaico-emdesenho do feijoeiro". Oprimeiro relato do mosaico-em-desenho ocorreu em São Paulo (Camargo et al., 1969), e posteriormente no Distrito Federal (Kitajima et al., 1980) e nos estados do Paraná (Bianchini et al., 1985), Minas Gerais e Goiás (Anjos 
et al., 1986). Lin et al. (1981), baseando-se no agrupamento dos comovírus em cinco sorogrupos (Fulton \& Scott, 1977), propuseram a reclassificação do "vírus do mosaico-em-desenho do feijoeiro" como uma estirpe do BRMV. Estimativas de perdas causadas pelo BRMV em feijoeiro indicam que a doença pode adquirir considerável importância econômica sob condições que lhe sejam favoráveis, com redução de produtividade de até 59\%. Maiores reduções no rendimento da cultura ocorrem em infecções precoces (14 dias após o plantio) e sob condições de infecção mista com outro(s) vírus (Anjos et al., 1994; Bianchini \& Bergamin Filho, 1994; Costa, 1983; Martins et al., 1994).

A gama de hospedeiros do BRMV está restrita a espécies de Chenopodiaceae e Fabaceae (Cupertino et al., 1991; Gamez, 1972; Gamez, 1982). Esse vírus é transmitido naturalmente por besouros crisomelídeos, como Cerotoma arcuata e Diabrotica speciosa (Coleoptera: Chrysomelidae) (Costa et al., 1981; Fulton \& Scott, 1977; Martins et al., 1994). Não é transmitido via semente em feijoeiro ou soja (Galvez et al., 1977; Gamez, 1972; Martins et al., 1994; Sperandio, 1982), mas é facilmente transmitido via extrato vegetal tamponado.

O BRMV pertence ao gênero Comovirus da família Comoviridae (Le Gall et al., 2005). O genoma dos comovírus é composto de duas moléculas de RNA de fita simples, sentido positivo, encapsuladas separadamente em partículas icosaédricas com diâmetro de 28 a $30 \mathrm{~nm}$. Os dois RNAs possuem uma proteína viral (VPg) ligada covalentemente à suas extremidades 5', e uma cauda poli-A nas extremidades 3'.

Em 2002, um isolado do BRMV foi obtido a partir de plantas de feijão-vagem do cultivar Novirex, coletadas no município de Cordisburgo, MG (Torres et al., 2003). As plantas apresentavam um sintoma atípico de vagens encurvadas em semicírculo, além de mosaico leve, sem ocorrência de deformação foliar. O vírus foi identificado inicialmente como um comovírus por meio de observações em microscópio eletrônico de transmissão, determinação da massa molecular das proteínas componentes do capsídeo viral e do comprimento dos RNAs genômicos. O resultado positivo obtido no ELISA indireto com anti-soro ao vírus (cedido pelo Prof. E.W. Kitajima, Escola Superior de Agricultura Luiz de Queiroz, Universidade de São Paulo, Piracicaba, SP) confirmou a identidade do isolado. Esse foi o primeiro relato de infecção de feijoeiro pelo BRMV em Minas Gerais em 17 anos.

$\mathrm{O}$ presente trabalho objetivou determinar a gama de hospedeiros deste isolado de BRMV, produzir anti-soro específico ao vírus, e estimar as perdas em feijoeiro devido à infecção simples ou mista com o Bean common mosaic virus (BCMV; Potyviridae, Potyvirus).

\section{MATERIAL E MÉTODOS}

\section{Manutenção do isolado viral}

$\mathrm{O}$ isolado de BRMV obtido por Torres et al. (2003) foi mantido e multiplicado em feijoeiros 'Ouro Negro', por meio de inoculação via extrato vegetal tamponado preparado a partir da trituração de folhas trifoliadas jovens com sintomas,

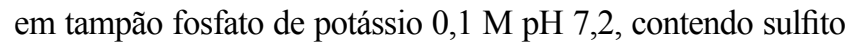

de sódio a $0,1 \%$. As plantas infectadas foram mantidas em condições de casa-de-vegetação. $\mathrm{O}$ inóculo recorrente consistiu de fragmentos recortados de folíolos sintomáticos jovens, que foram dessecados a $4{ }^{\circ} \mathrm{C}$ e mantidos a $-20^{\circ} \mathrm{C}$ dentro de pequenos frascos lacrados contendo sílica-gel.

$\mathrm{O}$ isolado de BCMV, utilizado no experimento de estimativa de perdas, pertence à estirpe ATCC (American Type Culture Collection, EUA) e foi adquirido comercialmente. O isolado foi mantido e multiplicado em feijoeiros 'Preto 153' da mesma forma descrita acima para o BRMV.

\section{Purificação do vírus}

Folhas de feijoeiros 'Ouro Negro' infectados pelo BRMV foram homogeneizadas, entre 15 e 30 dias após a inoculação, na proporção 1:2 de folhas para tampão fosfato de potássio $0,1 \mathrm{M} \mathrm{pH} 7,5$, contendo sulfito de sódio $0,5 \%$, e filtradas em gaze dupla. Em seguida foi adicionado ascorbato de sódio até a concentração final de $0,5 \%$, e o extrato foi centrifugado a $4.000 \mathrm{~g}$ por $10 \mathrm{~min}$. O sobrenadante foi clarificado com clorofórmio e $n$-butanol nas concentrações finais de $2,5 \%$ e $8 \%$, respectivamente, sob forte agitação. A emulsão foi centrifugada a $4.000 \mathrm{~g}$ por $10 \mathrm{~min}$, recolhendo-se a fase aquosa. Em seguida o vírus foi precipitado por meio da adição de polietilenoglicol 6.000 a uma concentração final de $6 \%$, com a mistura mantida sob agitação constante durante 60 min. Seguiu-se centrifugação a $7.800 \mathrm{~g}$ por $10 \mathrm{~min}$. O vírus no sedimento foi solubilizado em tampão fosfato de potássio 0,05

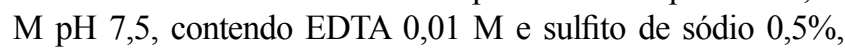
seguindo-se nova centrifugação a $7.000 \mathrm{~g}$ por $10 \mathrm{~min}$. $\mathrm{O}$ vírus foi reprecipitado ajustando-se o $\mathrm{pH}$ para 5,0 com ácido acético $10 \%$. Após uma hora em repouso, o precipitado resultante foi recolhido por centrifugação a $4.000 \mathrm{~g}$ por $10 \mathrm{~min}$. Em seguida o vírus foi solubilizado em tampão fosfato de potássio 0,2 $\mathrm{M} \mathrm{pH} 7,5$, uréia $0,5 \mathrm{M}$ e Triton X-100 0,1\% e centrifugado a $7.000 \mathrm{~g}$ por $10 \mathrm{~min}$, descartando-se o sedimento. $\mathrm{O}$ vírus foi concentrado mediante ultracentrifugação a $58.000 \mathrm{~g}$ por 165 min. O "pellet" foi ressuspendido em tampão fosfato de potássio $0,05 \mathrm{M} \mathrm{pH} 7,5$, seguindo-se centrifugação a $4.000 \mathrm{~g}$ por $10 \mathrm{~min}$. Por fim, realizou-se segunda ultracentrifugação, a $58.000 \mathrm{~g}$ por $165 \mathrm{~min}$, e o "pellet" foi ressuspendido em água destilada estéril. As preparações purificadas foram avaliadas qualitativamente mediante análise do espectro de absorção entre 220 e $340 \mathrm{~nm}$.

\section{Produção de anti-soro}

O vírus purificado foi injetado em dois coelhos brancos da raça Nova Zelândia, com cerca de 30 dias de idade. Após a coleta de sangue para a obtenção do soro normal (préimune), foi realizada uma injeção intravenosa com $1 \mathrm{mg}$ de vírus, veiculado em solução salina estéril. Posteriormente foram efetuadas cinco injeções intramusculares, com intervalos semanais, com 100,150,150, 200 e $200 \mu \mathrm{g}$ de vírus. A preparação viral foi emulsificada em igual volume de adjuvante incompleto de Freund antes de cada injeção intramuscular. Duas semanas após a última injeção foi retirada amostra de sangue a partir da veia marginal da 
orelha, para a verificação preliminar da qualidade e título do anti-soro. Cinco sangrias semanais adicionais foram realizadas após a sangria inicial. A especificidade de cada amostra semanal de anti-soro foi verificada em teste de difusão dupla em gel de agarose $(0,9 \%)$ em tris- $\mathrm{HCl} 0,02 \mathrm{M} \mathrm{pH} \mathrm{7,3,} \mathrm{contendo} \mathrm{NaCl}$ $0,85 \%$ e azida de sódio $0,01 \%$.

\section{Absorção do anti-soro com proteína total de feijoeiro}

A absorção do anti-soro foi realizada conforme descrito por Sperandio (1982). A fim de obter um extrato de proteína total de feijoeiro, folíolos sadios do cultivar Ouro Negro foram triturados a seco em almofariz. $\mathrm{O}$ extrato foi coado em gaze tripla, adicionando-se em seguida clorofórmio na proporção 1:2 (v/v). A solução foi mantida sob agitação constante por $10 \mathrm{~min}$ a $4{ }^{\circ} \mathrm{C}$. Após centrifugação a $700 \mathrm{~g}$ por $5 \mathrm{~min}$, a fase aquosa com a proteína total foi recolhida e armazenada a $4{ }^{\circ} \mathrm{C}$.

Para a absorção do anti-soro, alíquotas de $2 \mathrm{ml} \mathrm{da}$ solução de proteína total foram misturadas com igual volume de anti-soro em tubos sorológicos, e esta mistura foi mantida em banho-maria a $37{ }^{\circ} \mathrm{C}$ por 1 hora. Os tubos foram agitados freqüentemente, permanecendo um terço do tubo submerso, para formação de uma corrente de convecção. Essas alíquotas permaneceram em repouso por uma noite a $4{ }^{\circ} \mathrm{C}$, e em seguida foram centrifugadas a $3.800 \mathrm{~g}$ por 10 min, para remover do anti-soro os anti-corpos inespecíficos presentes no precipitado. $\mathrm{O}$ sobrenadante, constituindo o anti-soro absorvido, foi armazenado a $-20^{\circ} \mathrm{C}$.

\section{Análise do anti-soro}

O título e a especificidade dos anti-soros foram avaliados em ELISA indireto (Clark et al., 1986). O título foi determinado utilizando-se diluições 1:5.000, 1:10.000, 1:15.000, 1:20.000, 1:30.000, 1:40.000, 1:50.000, 1:60.000 e 1:70.000 de cada anti-soro em tampão PEP (Clark \& Adams, 1977). Os extratos foliares foram diluídos 1:5 em tampão de extração (Clark et al., 1986). Os resultados foram avaliados 25 min após a adição do substrato, em leitora Titertek Multiskan Plus MK II, a 405 nm.

\section{Gama de hospedeiros}

A determinação da gama de hospedeiros parcial do isolado de BRMV foi realizada utilizando-se plantas de 22 espécies/cultivares, membros das famílias Chenopodiaceae, Cucurbitaceae, Solanaceae e Fabaceae (Tabela 1). Foram inoculadas oito plantas de cada espécie/cultivar, e duas plantas foram utilizadas como testemunhas não inoculadas. Todas as plantas foram inoculadas via extrato vegetal tamponado conforme descrito anteriormente, e reinoculadas dois dias após a primeira inoculação. A fonte de inóculo consistiu de folhas de feijoeiro 'Ouro Negro' infectadas pelo BRMV. As plantas inoculadas foram mantidas em casa-de-vegetação, e a presença de sintomas foi avaliada visualmente 30 dias após a inoculação. A ocorrência de infecções latentes foi verificada por meio de ELISA indireto, realizado em todas as plantas que permaneceram assintomáticas até o final do período de avaliação.
TABELA 1 - Sintomas constatados em espécies/cultivares de plantas inoculadas via extrato vegetal tamponado com o isolado do Bean rugose mosaic virus

\begin{tabular}{|c|c|c|}
\hline Família & Espécie/cultivar & Sintomas \\
\hline \multirow{2}{*}{ Chenopodiaceae } & Chenopodium quinoa & $1 \mathrm{lc} / \mathrm{m}^{*}$ \\
\hline & Chenopodium amaranticolor & $-/-$ \\
\hline Cucurbitaceae & Cucumis sativus & $-/-$ \\
\hline Solanaceae & Nicotiana tabacum "White Burley" & $-/-$ \\
\hline \multirow[t]{21}{*}{ Fabaceae } & Glycine max & \\
\hline & cv. Cristalina & $-/-$ \\
\hline & cv. Bossier & $1 \mathrm{lc} / \mathrm{mb}$ \\
\hline & cv. Bragg & $-/ \mathrm{mb}$ \\
\hline & cv. Doko & $-/ \mathrm{mb}$ \\
\hline & cv. IAC 12 & $1 \mathrm{lc} / \mathrm{mb}$ \\
\hline & cv. Davis & $1 \mathrm{lc} / \mathrm{mb}$ \\
\hline & Phaseolus vulgaris & \\
\hline & cv. Jalo & $1 \mathrm{lc} / \mathrm{m}, \mathrm{na}$ \\
\hline & cv. Ouro Negro & $1 \mathrm{lc} / \mathrm{mb}, \mathrm{na}$ \\
\hline & cv. Manteigão & $-/ \mathrm{m}$ \\
\hline & cv. Rainha & $-/ \mathrm{m}$, na \\
\hline & cv. Carnaval & $-/ m b$, na \\
\hline & cv. Pérola & $-/-$ \\
\hline & cv. Novirex & $1 \mathrm{cc} / \mathrm{m}, \mathrm{ev}$ \\
\hline & cv. Turmalina & $-/ \mathrm{mb}$ \\
\hline & Vigna unguiculata & \\
\hline & cv. Clay & $-/-$ \\
\hline & cv. Pitiúba & $-/-$ \\
\hline & Vigna radiata & $-/-$ \\
\hline & Vigna umbellat a & l \\
\hline
\end{tabular}

*Sintomas em folhas inoculadas/não inoculadas, 30 dias após a inoculação: ev, enrolamento das vagens; llc, lesão local clorótica; m, mosaico; mb, mosaico com bolhosidade; na, necrose apical; - ausência de sintomas.

\section{Transmissão por besouros}

A transmissão do isolado de BRMV pelo vetor foi testada utilizando-se espécimes de Cerotoma arcuatus Olivier (Coleoptera, Chrysomelidae) coletados em soja, em área do Campo Experimental Diogo Alves de Mello, Universidade Federal de Viçosa (UFV). Os besouros passaram por um período prévio de alimentação em plantas sadias de feijoeiro 'Ouro Negro' com transferências sucessivas, para assegurar que estivessem avirulíferos. Em seguida os insetos foram transferidos para plantas de feijoeiro 'Ouro Negro' infectadas com o BRMV, nas quais foram mantidos por 48 horas (período de aquisição). A seguir foram transferidos para 6 novas plantas sadias de 'Ouro Negro', depositando-se 3 insetos por planta. Os vasos foram mantidos no interior de gaiolas teladas e desta forma o acesso dos insetos às plantas foi garantido nas próximas 24 horas (período de inoculação). Ao término desta fase, as plantas foram pulverizadas com inseticida (Imidacloprid), permanecendo em casa-de-vegetação para a avaliação visual da presença de sintomas. A infecção viral foi comprovada por meio de ELISA indireto, realizado em todas as plantas. 


\section{Estimativa de perdas em feijoeiro devido à infecção pelo BRMV e BCMV}

A fim de avaliar possíveis efeitos da infecção simples e mista pelo BRMV e BCMV em feijoeiro, plantas de 'Ouro Negro' e 'Novirex' foram estabelecidas em vasos plásticos contendo $10 \mathrm{~kg}$ de solo esterilizado, e inoculadas via extrato vegetal tamponado com o BRMV, BCMV ou ambos. $\mathrm{O}$ experimento foi estabelecido segundo delineamento inteiramente casualizado, constando de oito tratamentos: (i) plantas inoculadas apenas com o BRMV; (ii) inoculação apenas com o BCMV; (iii) BRMV e BCMV inoculados simultaneamente; (iv) inoculação do BRMV seguido do BCMV, após 7 dias; (v) inoculação do BRMV seguido do BCMV, após 21 dias; (vi) inoculação do BCMV seguido do BRMV, após 7 dias; (vii) inoculação do BCMV seguido do BRMV, após 21 dias; e (viii) testemunha inoculada apenas com solução tamponada. A primeira inoculação foi realizada 8 dias após a emergência das plântulas. Cada tratamento foi composto por seis vasos com duas plantas, num total de 12 plantas por tratamento. Cada vaso foi considerado como uma repetição, utilizando-se os valores médios das duas plantas, e o experimento foi realizado duas vezes. As plantas foram mantidas em casa-de-vegetação até 50 dias após a primeira inoculação. Foram avaliados o número médio de vagens por planta e o peso médio das vagens produzidas por planta. Os resultados foram submetidos a análise de variância utilizando-se o pacote estatístico SAS (SAS Institute, EUA) e as médias dos tratamentos comparadas pelo teste de Tukey, a $5 \%$ de probabilidade. A fim de comprovar a infecção de cada vírus, ou dos dois vírus simultaneamente nos diferentes tratamentos, folíolos de todas as plantas $(0,5 \mathrm{a} 1 \mathrm{~g})$ foram coletados cerca de uma semana antes da colheita e analisados por meio de ELISA indireto, utilizando-se o anti-soro para o BRMV e para a estirpe ATCC do BCMV, produzido na UFV (M.G. Carvalho, dados não publicados).

\section{RESULTADOS}

\section{Purificação do vírus}

O procedimento adotado possibilitou a obtenção do vírus purificado em rendimento e pureza satisfatórios. $\mathrm{O}$ rendimento médio calculado foi de 7,44 $\mathrm{mg}$ de vírus $/ \mathrm{kg}$ de folhas (dados não mostrados). $\mathrm{O}$ espectro de absorção do vírus purificado mostrou-se típico de uma nucleoproteína, com uma relação entre a absorbância a $260 \mathrm{~nm}$ e a $280 \mathrm{~nm}$ de 1,73 , equivalente à relatada para o BRMV não fracionado (Gamez, 1972).

\section{Produção e avaliação de anti-soro ao BRMV}

$\mathrm{Na}$ avaliação inicial dos anti-soros retirados dos dois coelhos imunizados, efetuada em testes de imunodifusão dupla em gel, linhas de precipitação se formaram entre antisoros e amostras de plantas sadias, indicando a ocorrência de reação inespecífica (dados não mostrados). Após absorção do anti-soro com proteína total de feijoeiro, este foi testado novamente por imunodifusão, constatando-se reação positiva restrita às plantas infectadas (dados não mostrados). A titulação dos anti-soros absorvidos foi realizada por meio de ELISA indireto, verificando-se reações positivas na diluição máxima testada (1:70.000) e nenhuma reação desses antisoros diante de extratos foliares de plantas sadias.

\section{Gama de hospedeiros}

As reações das plantas de 22 espécies/cultivares, pertencentes a 4 famílias botânicas, inoculadas via extrato vegetal tamponado como o isolado de BRMV, estão listadas na Tabela 1. Além da soja e do feijoeiro, o vírus infectou apenas Chenopodium quinoa Willd. Nessa planta foram observadas inicialmente lesões cloróticas nas folhas inoculadas, seguindo-se infecção sistêmica com mosaico e distorção foliar. Em soja e feijoeiro os sintomas evidentes foram mosaico foliar e bolhosidade, e necrose do ápice da planta. As demais espécies testadas não manifestaram nenhum sintoma e foram negativas no ELISA, confirmandose assim sua condição de não hospedeiras do vírus. Estes resultados estão de acordo com os dados da literatura para o BRMV (Gamez, 1982).

\section{Transmissão por besouros}

O BRMV foi transmitido por besouros da espécie Cerotoma arcuatus para plantas de feijoeiro 'Ouro Negro', que apresentaram os mesmos sintomas observados em plantas inoculadas via extrato vegetal tamponado. A transmissão do isolado pelo besouro crisomelídeo foi confirmada em todas as plantas que apresentavam sintomas, por meio de ELISA indireto. A transmissão ocorreu em 33,3\% dos casos (duas plantas das seis que receberam os besouros virulíferos).

\section{Estimativa de perdas em feijoeiro devido à infecção pelo BRMV e BCMV}

A análise estatística detectou interação significativa entre cultivares e tratamentos $(\mathrm{P}<0,05)$ e efeito significativo de cultivar e tratamento para as variáveis analisadas (número e peso de vagens por planta) (Tabela 2). Todas as plantas inoculadas foram analisadas por meio de ELISA indireto, confirmando-se a presença de cada vírus, de acordo com o tratamento (dados não mostrados).

O número médio de vagens por planta sadia da cultivar Novirex foi de 12,5, sem diferença significativa entre os tratamentos. Para a cultivar Ouro Negro, o número médio de vagens por planta sadia foi de 29,56. A inoculação simultânea dos dois vírus nesta cultivar causou queima do ápice e posterior morte das plantas, que não atingiram a fase reprodutiva. Os tratamentos em que a inoculação do BRMV precedeu à do BCMV, nos dois intervalos (7 e 21 dias), levaram a reduções de $82,5 \%$ e $88,5 \%$ no número médio de vagens por planta em relação à testemunha. Os tratamentos nos quais o BCMV precedeu ao BRMV apresentaram reduções de $64,3 \%$ e $48,5 \%$ (7 e 21 dias, respectivamente). Embora esses quatro tratamentos tenham diferido significativamente em relação à testemunha, eles não diferiram entre si. Nas plantas inoculadas com BRMV ou BCMV isoladamente, não se observou diferença 
Caracterização de um isolado do Bean rugose mosaic virus (BRMV)...

TABELA 2 - Número e peso de vagens por planta (média de seis repetições) observados em plantas de feijoeiro 'Novirex' e 'Ouro Negro' inoculadas com BRMV e BCMV, em diferentes combinações, em condições de casa-de-vegetação

\begin{tabular}{|c|c|c|c|c|c|c|c|c|c|c|c|c|}
\hline \multirow{3}{*}{ Tratamentos } & \multicolumn{6}{|c|}{ "Número de vagens/planta } & \multicolumn{6}{|c|}{ Peso de vagens/planta } \\
\hline & \multicolumn{3}{|c|}{ Novire $x$} & \multicolumn{3}{|c|}{ Ouro Negro } & \multicolumn{3}{|c|}{ Novirex } & \multicolumn{3}{|c|}{ Ouro Negro } \\
\hline & \multicolumn{2}{|c|}{ número } & \multirow{2}{*}{$\frac{\text { \% }^{\text {red. }}{ }^{\S}}{-}$} & \multicolumn{2}{|c|}{ número } & \multirow{2}{*}{$\begin{array}{c}\text { \% red. } \\
-\end{array}$} & \multicolumn{2}{|c|}{ gramas } & \multirow{2}{*}{ \% red. } & \multicolumn{2}{|c|}{ gramas } & \multirow{2}{*}{ \% red. } \\
\hline Testemunha & 12,50 & $a^{9}$ & & 29,56 & $\mathrm{a}$ & & 32,82 & $\mathrm{a}$ & & 30,62 & $\mathrm{a}$ & \\
\hline Simultâneo & 7,78 & $\mathrm{a}$ & 37,76 & 0 & $\mathrm{c}$ & 100 & 12,92 & $\mathrm{c}$ & 60,63 & 0 & $\mathrm{c}$ & 100 \\
\hline BCMV - BRMV (7 dias) & 7,00 & $\mathrm{a}$ & 44,00 & 10,55 & $\mathrm{~b}$ & 64,31 & 10,92 & $\mathrm{c}$ & 66,72 & 15,55 & $\mathrm{~b}$ & 49,22 \\
\hline BRMV - BCMV (7 dias) & 6,44 & $\mathrm{a}$ & 48,48 & 5,17 & bc & 82,51 & 11,14 & $\mathrm{c}$ & 66,06 & 5,41 & $\mathrm{c}$ & 82,33 \\
\hline BCMV - BRMV (21 dias) & 10,28 & $\mathrm{a}$ & 17,76 & 15,22 & $\mathrm{~b}$ & 48,51 & 12,79 & $\mathrm{c}$ & 61,03 & 20,18 & $\mathrm{~b}$ & 34,09 \\
\hline BRMV - BCMV (21 dias) & 7,06 & $\mathrm{a}$ & 43,52 & 3,39 & bc & 88,53 & 9,81 & $\mathrm{c}$ & 70,11 & 2,82 & $\mathrm{c}$ & 90,80 \\
\hline BRMV & 6,17 & a & 50,62 & 27,72 & $\mathrm{a}$ & 6,20 & 4,97 & $\mathrm{c}$ & 84,86 & 29,58 & a & 3,40 \\
\hline BCMV & 10,61 & $\mathrm{a}$ & 15,93 & 30,28 & $\mathrm{a}$ & $-2,43$ & 21,23 & $\mathrm{~b}$ & 35,31 & 28,16 & a & 8,03 \\
\hline C.V. $(\%)$ & \multicolumn{6}{|c|}{36,05} & \multicolumn{6}{|c|}{23,98} \\
\hline
\end{tabular}

" Médias seguidas pelas mesmas letras nas colunas não diferem entre si ao nível de $5 \%$ probabilidade, pelo teste de Tukey.

§Porcentagem de redução no número e no peso das vagens em relação à testemunha.

estatisticamente significativa no número médio de vagens por planta em relação à testemunha.

Embora ambas as variáveis testadas tenham levado a resultados semelhantes, a variável "peso médio de vagens por planta" permitiu diferenciar melhor os efeitos dos tratamentos em comparação à variável "número médio de vagens por planta" (Tabela 2). O peso médio das vagens produzidas pelas plantas sadias de 'Novirex' foi de 32,8 g. Para esta cultivar, todos os tratamentos apresentaram redução significativa no peso médio das vagens em relação à testemunha. As plantas inoculadas apenas com o BCMV mostraram a menor porcentagem de redução (35,3\%), ao passo que infecção isolada com o BRMV levou à maior porcentagem de redução $(84,9 \%)$. A infecção mista pelos dois vírus levou a reduções menores, porém sem diferença estatisticamente significativa em relação à infecção simples pelo BRMV. Em conjunto, estes resultados indicam que a cultivar Novirex é suscetível aos dois vírus, porém particularmente ao BRMV.

O peso médio das vagens produzidas pelas plantas sadias de 'Ouro Negro' foi de 30,6 g. As menores reduções foram observadas em plantas inoculadas isoladamente com o $\operatorname{BRMV}(3,4 \%)$ ou com o $\operatorname{BCMV~(8\% ),~valores~que~não~}$ diferiram significativamente em relação à testemunha. Estas porcentagens de redução foram muito menores em comparação à cultivar Novirex. Reduções drásticas foram observadas na inoculação simultânea $(100 \%)$ e quando o BRMV foi inoculado anteriormente ao BCMV (82,3 e 90,8\%, 7 e 21 dias, respectivamente). Em conjunto, estes resultados indicam que 'Ouro Negro' é moderadamente resistente aos dois vírus em infecções simples, porém suscetível no caso de infecção mista e particularmente quando o BRMV é inoculado anteriormente ao BCMV.

\section{DISCUSSÃO}

Os resultados de estudos anteriores realizados na UFV, incluindo microscopia eletrônica, eletroforese da proteína e ácido nucléico virais e sorologia, indicaram que o isolado viral coletado em Cordisburgo em 2002 em feijoeiros 'Novirex' é um comovírus (Torres et al., 2003). Ao microscópio eletrônico de transmissão foram observadas inclusões citoplasmáticas poligonais, visualmente idênticas às relatadas para o BRMV e para o "vírus do mosaico-emdesenho do feijoeiro". A sintomatologia observada nas plantas infectadas foi a mesma descrita para o mosaico rugoso em países da América Central (Gamez, 1982) e para o mosaico-em-desenho no Brasil (Cupertino et al., 1991; Cupertino et al., 1982). A análise eletroforética indicou a presença de duas proteínas capsidiais e de dois RNAs genômicos. Finalmente, anti-soro para BRMV reagiu com o isolado em ELISA indireto (Torres et al., 2003).

No presente trabalho verificou-se que o isolado é transmitido de forma circulativa por besouros crisomelídeos, uma propriedade excludente de potyvírus e begomovírus causadores de mosaico em feijoeiro.

Embora o processo de purificação adotado tenha sido bem sucedido, permitindo a obtenção de anti-soro de alta especificidade para este isolado de BRMV, estranhou-se a dificuldade encontrada em obtê-lo na forma pura. Sabese que comovírus como Squash mosaic virus e Bean pod mottle virus, e o próprio BRMV, não requerem cuidados maiores nas purificações (Acosta et al., 1986; Galvez et al., 1977; Gamez, 1972; Martins et al., 1994). Entretanto, com o isolado em estudo, foi preciso aprimorar o método e não se logrou separar em gradiente de sacarose, nas etapas finais da purificação, os três componentes ("top", "middle" e "bottom"), provavelmente presentes na preparação viral. Também não se verificou a presença de banda viral após 18 horas de ultracentrifugação isopícnica em $\mathrm{CsCl}$. No entanto, foi satisfatória a preparação final obtida, cujo espectro de absorbância em UV é típico de nucleoproteínas, além de ter sido possível preparar anti-soro específico (após a remoção dos anticorpos a imunógenos da planta) e de bom título (1:70.000 em ELISA indireto). A reatividade inicial do antisoro diante de extratos de folha sadia era esperada, visto que, verificada inviável a centrifugação de equilíbrio em $\mathrm{CsCl}$, não 
havia como remover moléculas protéicas e nucleoproteínas de origem celular com o método de purificação utilizado.

A maneira pela qual os patógenos interagem com o hospedeiro, e entre si, nas infecções e no desencadeamento de perdas às plantas cultivadas, tem implicações importantes na avaliação dos danos finais às culturas, na identificação das causas das doenças e na seleção adequada das medidas de controle. Os danos causados ao hospedeiro na infecção mista podem ser maiores, menores ou iguais à soma dos prejuízos atribuídos a cada patógeno em infecção simples (Hull, 2002).

Em 'Novirex', a redução de peso das vagens diferiu significativamente da testemunha em todos os sete tratamentos, e em 'Ouro Negro', em cinco. No presente estudo, e de acordo com as variáveis avaliadas, os percentuais de redução dependeram da espécie viral, do cultivar e da seqüência de inoculação dos dois vírus.

'Novirex' e 'Ouro Negro' apresentaram porcentagens de redução no peso médio de vagens por planta de $84,9 \%$ e $3,4 \%$, respectivamente, na infecção simples pelo BRMV, e de $35,3 \%$ e $8 \%$, respectivamente, na infecção simples pelo BCMV, evidenciando a maior suscetibilidade da primeira cultivar a ambos os vírus, em relação à segunda. A redução do peso médio de vagens em 'Novirex' foi significativamente maior para o BRMV em relação ao BCMV. Em 'Ouro Negro' os valores não diferiram entre si ou mesmo em relação à testemunha, indicando que esta cultivar é moderadamente resistente à infecção simples por ambos os vírus, um resultado que deve ser confirmado em estudos posteriores.

Em estudo semelhante, os maiores percentuais de redução da produção de feijoeiro 'Capixaba Precoce' e 'Carioca' infectados com o BRMV em diferentes épocas foram de $54 \%$ e $57 \%$, respectivamente, para plantas infectadas mais cedo (14 dias após a emergência), com reduções muito menores nas inoculações aos 28 e 48 dias (Yokoyama, 2000). Costa (1983) relatou que o rendimento do feijão 'Rosinha G-2' decresceu $48 \%$ na infecção simples pelo BRMV, e em $67 \%$ na infecção mista com o BCMV. Observa-se assim uma alta suscetibilidade dessas cultivares ao BRMV, o que torna a possível resistência de 'Ouro Negro' ao vírus particularmente atraente para programas de melhoramento.

Os dados obtidos no presente trabalho evidenciam o efeito drástico da infecção mista pelo BCMV e BRMV em 'Ouro Negro', com a indução de queima do ápice e posterior morte das plantas. Um fato relevante é a influência da ordem de inoculação dos dois vírus no efeito sinérgico. As reduções no peso médio de vagens por planta foram maiores (e estatisticamente significativas) quando o BRMV foi inoculado anteriormente ao BCMV. Martins et al. (1994) relataram sinergismo em soja 'OCEPAR-4-Iguaçu' entre o BRMV e o potyvírus Soybean mosaic virus (SMV), com base em uma redução de $83 \%$ no peso da matéria seca e de $82 \%$ na área foliar, em relação à testemunha não inoculada. Os decréscimos foram de apenas $61 \%$ e $52 \%$ respectivamente para plantas inoculadas isoladamente com o BRMV, e de
$68 \%$ e $62 \%$ em infecção simples pelo SMV. Os autores atribuíram a ação sinérgica à necrose apical tendendo para necrose sistêmica, que ocorreu apenas naquela cultivar e na infecção mista.

Os resultados aqui relatados sugerem que a possível resistência de 'Ouro Negro' ao BRMV e BCMV é quebrada em caso de infecção mista, e que a quebra de resistência é mais efetiva quando o BRMV é inoculado anteriormente ao BCMV. Porém, não se conhece o mecanismo da resistência demonstrada por essa cultivar ao BRMV. Estudos posteriores deverão identificar a natureza dessa resistência, bem como o possível mecanismo de quebra da resistência na infecção mista.

A extrema suscetibilidade da cultivar 'Novirex', bem como o sintoma atípico de enrolamento das vagens apresentado por ela, podem afetar a sua produção já que trata-se de uma cultivar de feijão-vagem, na qual o formato da vagem é uma característica essencial do produto final. Em cultivares nas quais se comercializa o grão, o formato da vagem é irrelevante ou pode passar despercebido. Embora não existam dados de incidência e prevalência do BRMV no campo, esses resultados sugerem que o BRMV pode ser responsável por perdas significativas na produção de feijão em Minas Gerais.

\section{REFERÊNCIAS BIBLIOGRÁFICAS}

ACOSTA, O., ALEGRÍA, A. \& LASTRA, R. Some biological and physicochemical properties of Bean rugose mosaic virus. Phytopathology 76:1182-1189. 1986.

ANJOS, J.R.N., COSTA, A.S., SPERANDIO, C.A. \& COSTA, C.L. Mosaico-em-desenho. In: Rava, C.A. (Ed.) Principais doenças do feijoeiro comum e seu controle. Brasília, EMBRAPA/CNPAF: 1994. pp.285-300

ANJOS, J.R.N., COSTA, C.L. \& KITAJIMA, E.W. Levantamento de viroses em cultura de feijão irrigado na região dos Cerrados. Fitopatologia Brasileira 11:391. 1986. (Resumo)

BIANCHINI, A. \& BERGAMIN FILHO, A. Reação induzida em feijoeiro pela interação do vírus do mosaico dourado e do mosaicoem-desenho. pp.21 In: Seminário sobre pragas, doenças e plantas daninhas do feijoeiro. Piracicaba: FEALQ. 1994.

BIANCHINI, A., KITAJIMA, E.W. \& LIN, M.T. Ocorrência do virus do mosaico-em-desenho do feijoeiro no Estado do Paraná. Fitopatologia Brasileira 10:307. 1985.

CAMARGO, I.J.B., KITAJIMA, E.W. \& COSTA, A.S. Inclusões cristalinas de um vírus isodiamétrico que afeta o feijoeiro. Ciência e Cultura 21:490. 1969.

CLARK, M.F. \& ADAMS, A.N. Caracteristics of the microplate method of enzyme-linked immunosorbent assay for detection of plant viruses. Journal of General Virology 34:475-483. 1977.

CLARK, M.F., LISTER, R.M. \& BAR-JOSEPH, M. ELISA techniques. Methods in Enzymology 118:742-766. 1986.

COSTA, A.F. Efeito das infecções simples e duplas de quatro vírus 
do feijoeiro (Phaseolus vulgaris L.) na produção e em algumas características da planta. Tese de Mestrado, Universidade de Brasília, Brasília. 1983.

COSTA, C.L., LIN, M.T. \& SPERANDIO, C.A. Besouros crisomelídeos vetores do sorotipo IV do "Cowpea severe mosaic virus" isolado de feijoeiro. Fitopatologia Brasileira 6:523. 1981.

CUPERTINO, F.P., COSTA, C.L. \& KITAJIMA, E.W. Infecção natural da soja pelo vírus do mosaico-em-desenho do feijoeiro, no Distrito Federal. Fitopatologia Brasileira 16:246-250. 1991.

CUPERTINO, F.P., COSTA, C.L., LIN, M.T. \& KITAJIMA, E.W. Infecções simples e mistas dos virus do mosaico-do-sul e do mosaico-em-desenho em feijão-vagem no Brasil central. Fitopatologia Brasileira 7:269-274. 1982.

FULTON, J.P. \& SCOTT, H.A. Bean rugose mosaic and related viruses and their transmission by beetles. Fitopatologia Brasileira 2:9-16. 1977.

GALVEZ, G., CARDENAS, M., KITAJIMA, E.W., DIAZ, A. \& NIETO, M. Purification, serology, eletron microscoy and properties of Ampollado strain of bean rugose mosaic virus. Turrialba 27:343350. 1977.

GAMEZ, R. Los vírus del fríjol en Centro América. II. Algunas propiedades y transmisión por crisomélidos del vírus del mosaico rugoso del frijol. Turrialba 22:249-257. 1972.

GAMEZ, R. Bean rugose mosaic virus. In: CMI/AAB Descriptions of plant viruses No. 246. 1982.

HULL, R. Matthew's Plant Virology 4a ed.. Londres. Academic Press. 2002.
KITAJIMA, E.W., LIN, M.T., COSTA, C.L. \& BATISTA, M.F. Ocorrência do virus do mosaico-em-desenho do feijoeiro no Distrito Federal. Fitopatologia Brasileira 5:408. 1980.

LE GALL, O., IWANAMI, T., KARASEV, A.V., JONES, T., LEHTO, K., SANFAÇON, H., WELLINK, J., WETZEL, T. \& YOSHIKAWA, N. Family Comoviridae. In: Fauquet, C., Mayo, M.A., Maniloff, J., Desselberger, U. \& Ball, L.A. (Eds.) Virus Taxonomy. Eighth Report of the International Committee on Taxonomy of Viruses. San Diego, EUA: Elsevier Academic Press. 2005. pp.807-818

LIN, M.T., GAMEZ, R.G. \& KITAJIMA, E.W. Bean "mosaicoem-desenho" virus is a member of the bean rugose mosaic virus serogroup. Fitopatologia Brasileira 6:293-298. 1981.

MARTINS, T.R., ALMEIDA, A.M.R., ALMEIDA, L.A., NEPOMUCENO, A., CHAGAS, C.M. \& TOLEDO, J.F.F. Sinergismo observado em plantas de soja infectadas pelos vírus do mosaico comum da soja e do mosaico-em-desenho do feijoeiro. Fitopatologia Brasileira 19:430-436. 1994.

SPERANDIO, C.A. Caracterização do vírus do mosaico-emdesenho do feijoeiro (Phaseolus vulgaris L.). Tese de Mestrado, Universidade de Brasília, Brasilia. 1982.

TORRES, L.B., MOREIRA, A.G., CASTILLO-URQUIZA, G.P., CARVALHO, M.G., MATSUOKA, K. \& ZERBINI, F.M. Detection of an isolate of Bean rugose mosaic virus (BRMV) infecting beans in Minas Gerais state. Virus Reviews and Research 8:154. 2003.

YOKOYAMA, L.P. Cultura do feijoeiro no Brasil: características da produção. Santo Antônio de Goiás: Embrapa Arroz e Feijão. 2000 . 